\title{
Ancestral Caddo Ceramic Assemblage from the Spoonbill Site (41WD109) in the Lake Fork Creek Basin, Wood County, Texas
}

Timothy K. Perttula

Heritage Research Center, Stephen F. Austin State University

Bob D. Skiles

Follow this and additional works at: https://scholarworks.sfasu.edu/ita

Part of the American Material Culture Commons, Archaeological Anthropology Commons, Environmental Studies Commons, Other American Studies Commons, Other Arts and Humanities Commons, Other History of Art, Architecture, and Archaeology Commons, and the United States History Commons

Tell us how this article helped you.

This Article is brought to you for free and open access by the Center for Regional Heritage Research at SFA ScholarWorks. It has been accepted for inclusion in Index of Texas Archaeology: Open Access Gray Literature from the Lone Star State by an authorized editor of SFA ScholarWorks. For more information, please contact cdsscholarworks@sfasu.edu. 
Ancestral Caddo Ceramic Assemblage from the Spoonbill Site (41WD109) in the Lake Fork Creek Basin, Wood County, Texas

\section{Creative Commons License}

\section{(c) (1) (8)}

This work is licensed under a Creative Commons Attribution-NonCommercial 4.0 International License 


\title{
Ancestral Caddo Ceramic Assemblage from the Spoonbill Site (41WD109) in the Lake Fork Creek Basin, Wood County, Texas
}

\author{
Timothy K. Perttula and Bob D. Skiles
}

\section{Introduction}

Ancestral Caddo habitation sites are common in the upper Sabine River basin in East Texas, as well as along tributaries of the Sabine River, including Lake Fork Creek. In this article we discuss the ceramic vessel sherd assemblages from the Spoonbill site (41WD109) that was investigated in the area in the 1970s. The site is in the Lake Fork Creek basin in the immediate vicinity of Lake Fork Reservoir (Bruseth and Perttula 1981) (Figure 1).

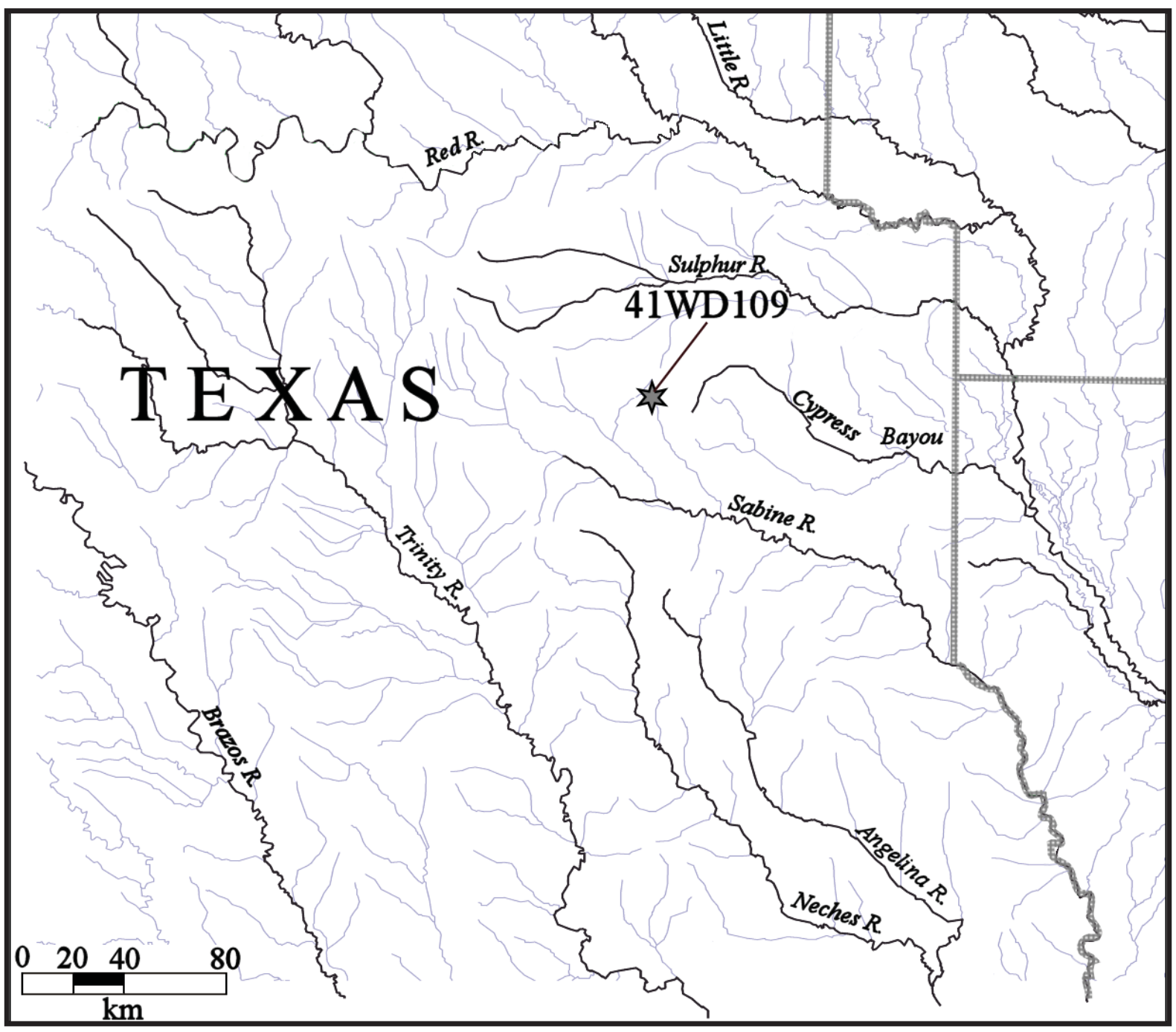

Figure 1. General location of the Spoonbill site in Wood County, Texas. 


\section{Spoonbill (41WD109)}

The Spoonbill site is an important multi-component Caddo settlement and cemetery on an upland landform overlooking the Caney Creek floodplain in the Lake Fork Creek drainage basin (see Figure 1). The first component dates to the Middle Caddo period, and includes numerous cultural features, portions of a circular house structure, several burial features (4+), and well-preserved plant remains (Bruseth and Perttula 1981; Perttula et al. 1982; Skiles 1981), mainly from work done in 1978. The second component is represented by a post-A.D. 1550 Titus phase cemetery with at least 14 burials; most of these burials were excavated in 1967 by J. A. Walters (Perttula et al. 2009), but one burial feature from this component was excavated in 1978 (Skiles 1981), and others had been previously dug by a local avocationalist (Marlon Weir).

There are a number of vessels from both Middle Caddo and Late Caddo period burials found in the same cemetery. The Middle Caddo period ceramic vessels include a red-slipped and punctated bottle (cf. Maxey Noded Redware), an interior and exterior engraved bowl (probably a Spoonbill Engraved vessel), a red-slipped incised-punctated bowl, two Monkstown Fingernail Impressed jars, an incised jar, two Spoonbill Engraved bowls, and three Sanders Engraved carinated bowls (Perttula et al. 2009; Bruseth and Perttula 1981:Table 5-10). The Titus phase graves include vessels of the following identified ceramic types: Hodges Engraved, Hudson Engraved, Keno Trailed, var. Phillips, La Rue Neck Banded, McKinney Appliqued, Mockingbird Punctated, Ripley Engraved, Simms Engraved, var. Darco, and Taylor Engraved (Perttula et al. 2009; Bruseth and Perttula 1981:Table 5-10).

The ceramic assemblage from the Spoonbill site discussed in this article was collected in the late 1970s from surface contexts by Bob D. Skiles and James E. Bruseth. It consists of 197 sherds: 150 plain rim, body, and base sherds, and 47 decorated sherds; the plain to decorated sherd ratio is 3.19. All of the sherds are from grog-tempered vessels; one sherd ( 0.5 percent) has grog and bone temper.

The 47 decorated sherds include sherds from both utility ware $(n=31,66$ percent) and fine ware $(\mathrm{n}=16,34$ percent) vessels (Table 1$)$. Most of the utility ware sherds are from Canton Incised vessels with diagonal and diagonal opposed incised decorative elements $(n=11,35.5$ percent of the utility wares) and sherds with tool or cane punctated rows ( $n=9,29.0$ percent). There are also four sherds with appliqued fillet or appliqued ridge elements, three corn cob impressed sherds, one pinched sherd, one neck banded sherd, a sherd with horizontal brushing marks, and another sherd with parallel brushing marks adjacent to a row of tool punctations; the brushed and brushed-punctated sherds are likely from Bullard Brushed vessels.

Table 1. Decorative methods and elements in the Spoonbill site (41WD109) ceramic sherd assemblage.

\begin{tabular}{llll}
\hline Decorative method and elements & Rim & Body & $\mathrm{N}$ \\
\hline
\end{tabular}

Utility ware

Appliqued

straight appliqued fillet

straight appliqued ridge

$\begin{array}{lll}- & 2 & 2\end{array}$

2

Brushed

horizontal brushed

Brushed-Punctated

parallel brushed and adjacent tool punctated row 
Table 1. Decorative methods and elements in the Spoonbill site (41WD109) ceramic sherd assemblage, cont.

\begin{tabular}{llll}
\hline Decorative method and elements & Rim & Body & N \\
\hline
\end{tabular}

\section{Utility ware, cont.}

\section{Corn Cob Impressed}

random corn cob impressed

\section{Incised}

diagonal incised lines

diagonal opposed incised lines

parallel incised lines

straight incised line

vertical incised lines

\section{Neck Banded}

parallel neck bands

\section{Pinched}

vertical pinched ridge

\section{Punctated}

cane punctated rows

tool punctated rows

\section{Fine ware}

\section{Engraved}

cross-hatched engraved lines

diagonal engraved lines

horizontal engraved lines, closely-spaced

horizontal engraved line under the lip

horizontal-diagonal engraved lines

horizontal engraved line and diagonal hatched vertical

zone

horizontal and vertical zones with diagonal hatched lines

horizontal engraved lines and horizontal hatched

vertical zone

parallel engraved lines

straight engraved line

vertical engraved lines

\section{Red-Slipped}

ext. red-slipped

int./ext. red-slipped

Totals

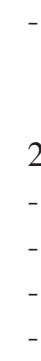

2

$-\quad 1$

1

3

3

1

1

1

1

1

$\begin{array}{lll}- & 1 & 1 \\ 2 & 6 & 8\end{array}$

Several of the utility ware sherds are from Late Caddo period Titus phase vessels. This includes the two brushed/brushed-punctated Bullard Brushed sherds, a La Rue Neck Banded sherd, and the three 
corn cob impressed sherds; the appliqued sherds may be from McKinney Appliqued jars. The corn cob impressed sherds are from Anglin Corn Cob Impressed vessels, first defined in the assemblage of $16^{\text {th }}$ and $17^{\text {th }}$ century utility wares from the Tuinier Farm (41HP237) and Anglin (41HP240) sites in the Stouts Creek basin in the upper White Oak Creek drainage (Perttula 2009). The Anglin Corn Cob impressed rim and body sherds are marked by roughly parallel or horizontal rows of impressions created by rolling a corn cob across the wet surface of an unfired jar. Corncob impressed pottery had been previously identified in the ceramic sherd assemblage at the Spoonbill site (Bruseth and Perttula 1981:Table 5-8 and 82), where it was dubbed "Corn Cobb Incised."

The fine ware sherds in the Spoonbill site ceramic assemblage include both engraved $(n=14)$ and redslipped $(n=2)$ sherds (see Table 1). The red-slipped sherds are from Sanders Slipped (previously defined as Sanders Plain) vessels, and two of the engraved sherds (with cross-hatched and diagonal-horizontal decorative elements) are from Sanders Engraved vessels. The most distinctive of the engraved sherds are three rim or body sherds with narrow vertical and/or horizontal zones filled with either horizontal or diagonal hatched lines (Figure 2a-c). No Titus phase fine ware engraved sherds are present in this ceramic assemblage from the Spoonbill site.

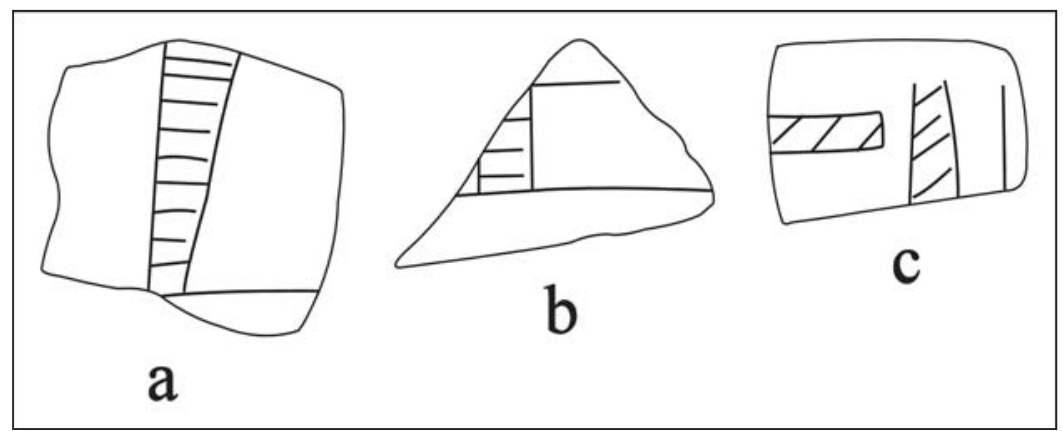

Figure 2. Selected fine ware decorative elements in the Spoonbill site sherds.

\section{Summary and Conclusions}

The analysis of the ceramic vessel sherd assemblage from the Spoonbill site (41WD109) provides further archaeological evidence attesting to the substantial settlement of this part of East Texas by Caddo peoples during both the Middle Caddo (ca. A.D. 1200-1400) and Late Caddo (ca. A.D. 1400-16880) periods. The ceramic assemblage at the site is comprised of grog-tempered plain ware, utility ware, and fine ware vessel sherds.

Middle Caddo period ceramic assemblages are present at the Spoonbill site. Previous excavations at a cemetery at the Spoonbill site have recovered comparable Sanders Engraved and Canton Incised vessels as funerary offerings, as well as Maxey Noded Redware, Spoonbill Engraved, and Monkstown Fingernail Impressed vessels. The Upper Sabine River Middle Caddo period sites do apparently share stylistic characteristics with Sanders phase sites on the middle Red River (Jackson et al. 2000; Perttula et al. 2015), and contemporaneous sites elsewhere in the upper and mid-Sabine River basin (Perttula 2015a; Perttula et al. 1993a).

Late Caddo period Titus phase ceramic vessel sherds are also present at the Spoonbill site from habitation contexts, and the site also has a Titus phase cemetery. The vessel sherds are from Ripley Engraved fine ware vessels, as well as sherds from Anglin Corn Cob Impressed, Bullard Brushed, La Rue Neck Banded, Maydelle Incised, and McKinney Appliqued utility ware vessels. The burial features with associated ceramic vessel funerary offerings at the Spoonbill site include such types as Simms Engraved, Taylor Engraved, and cf. Womack Engraved, as well as Ripley Engraved, Wilder Engraved, and La Rue Neck Banded vessels (Perttula et al. 2009; Skiles 1981), that suggest these features are from a post- 
A.D. 1550 Titus phase component. Such components are common in both the Caney Creek (Bruseth and Perttula 1981; Perttula et al. 2009) and Dry Creek (Perttula 2005, 2015a, 2015b, 2016a, 2016b; Perttula and Skiles 2014a, 2014b; Perttula and Walters 2016; Perttula et al. 1993b) drainages in the Lake Fork Creek drainage basin, and they include habitation sites - farmsteads and small hamlets - along with family cemeteries.

\section{Acknowledgments}

Lance Trask prepared the figures in this article.

\section{References Cited}

Bruseth, J. E. and T. K. Perttula

1981 Prehistoric Settlement Patterns at Lake Fork Reservoir. Texas Antiquities Permit Series, Report No. 2. Texas Antiquities Committee and Southern Methodist University, Austin and Dallas.

Jackson, A. T., M. S. Goldstein, and A. D. Krieger

2000 The 1931 Excavations at the Sanders Site, Lamar County, Texas: Notes on the Fieldwork, Human Osteology, and Ceramics. Archival Series 2. Texas Archeological Research Laboratory, The University of Texas at Austin.

Malone, J. M.

1972 Archaeological Reconnaissance at Proposed Mineola Reservoir. Archeological Survey Report No. 10. Texas Historical Survey Committee, Austin.

Perttula, T. K.

2005 The M. W. Burks Site (41WD52), A Late Caddo Hamlet in Wood County, Texas. Journal of Northeast Texas Archaeology 23:1-27.

2009 The Archaeology of the $16^{\text {th }}$ and $17^{\text {th }}$ Century Caddo in the Post Oak Savannah of Northeast Texas: The Tuinier Farm (41HP237), R. A. Watkins (41HP238), and Anglin (41HP240) Sites in the Stouts Creek Basin, Hopkins County, Texas. Journal of Northeast Texas Archaeology 30:1-132.

2015a The A. C. Gibson Site (41WD1), a Middle Caddo Period Component on the Sabine River in Wood County, Texas. Journal of Northeast Texas Archaeology 53:37-46.

2015b A Titus Phase Midden Mound at the Earl Jones Farm (41WD3) in the Lake Fork Creek Basin, Wood County, Texas. Journal of Northeast Texas Archaeology 53:11-21.

2015c The L. L. Winterbauer Site (41WD6), Wood County, Texas. Journal of Northeast Texas Archaeology 53:23-35.

2016a Caddo Vessels from the W. O. Ziegler Farm (41WD30) and Claude Burkett (41WD31) Sites in the Upper Sabine River Basin in Wood County, Texas. Journal of Northeast Texas Archaeology 64:93-97.

2016b Titus Phase Ceramics from the Pine Tree Farm Site (41WD51) in the Lake Fork Creek Basin, Wood County, Texas. Journal of Northeast Texas Archaeology 67:75-78.

Perttula, T. K. and B. D. Skiles

2014a The Steck Site (41WD529), a Titus Phase Settlement in the Lake Fork Creek Drainage Basin, Wood County, Texas. Journal of Northeast Texas Archaeology 48:1-8.

2014b Documentation of Late Caddo Period Ceramic Vessels from Sites in the Lake Fork Creek Basin in Wood County, Texas. Journal of Northeast Texas Archaeology 48:59-81.

Perttula, T. K. and M. Walters

2016 Ceramic Vessels from Caddo Sites in Wood County, Texas. Journal of Northeast Texas Archaeology 63:75-131. 
Perttula, T. K., C. J. Crane, and J. E. Bruseth

1982 A Consideration of Caddoan Subsistence. Southeastern Archaeology 1(2):89-102.

Perttula, T. K., B. Nelson, M. Walters, and R. Z. Selden Jr.

2015 The Sanders Site (41LR2): A Middle to Historic Caddo Settlement and Mound Center on the Red River in Lamar County, Texas. Journal of Northeast Texas Archaeology 50:1-87.

Perttula, T. K., B. D. Skiles, and B. C. Yates

1993a The Carlisle Site (41WD46), a Middle Caddoan Occupation on the Sabine River, Wood County, Texas. Notes on Northeast Texas Archaeology 1:34-62.

1993b Excavations at the Goldsmith Site (41WD208): Investigations of the Titus Phase in the Upper Sabine River Basin, Wood County, Texas. Bulletin of the Texas Archeological Society 61:139-191.

Perttula, T. K., M. Walters, S. Marceaux, and B. Nelson

2009 Caddo Pottery Vessels and Pipes from Sites in the Middle and Upper Sabine and Upper Neches River Basins, Smith and Wood Counties, Texas. Special Publication No. 7. Friends of Northeast Texas Archaeology, Pittsburg and Austin.

Skiles, B. D.

1981 Spoonbill Site (41WD109). In Prehistoric Settlement Patterns at Lake Fork Reservoir, by J. E. Bruseth and T. K. Perttula, pp. 40-48. Texas Antiquities Permit Series, Report No. 2. Texas Antiquities Committee and Southern Methodist University, Austin and Dallas. 